Marquette University

e-Publications@Marquette

$1-1-2006$

College Students' Responses to Antismoking Messages: Denial, Defiance, and Other Boomerang Effects

Joyce M. Wolburg

Marquette University, joyce.wolburg@marquette.edu

Accepted version. Journal of Consumer Affairs, Vol. 40, No. 2 (Winter 2006): 294-323. DOI. (C) 2006 John Wiley \& Sons, Inc. Used with permission. 
NOT THE PUBLISHED VERSION; this is the author's final, peer-reviewed manuscript. The published version may be accessed by following the link in the citation at the bottom of the page.

\title{
College Students' Responses to Antismoking Messages: Denial, Defiance, and Other Boomerang Effects
}

\author{
Joyce M. Wolburg \\ Diederich College of Communication, Marquette University \\ Milwaukee, WI
}

\begin{abstract}
Despite the success of antismoking campaigns that aim to prevent young teens from smoking, this qualitative study provides strong evidence that different initiatives are needed for college students, particularly those who already smoke. When asked for responses to current antismoking messages, nonsmokers generally championed the cause; however, smokers often responded with anger, defiance, denial, and other negative responses. Consumers who respond in this manner are not well served by existing strategies, and money used for such campaigns could be better spent. New strategies are offered in hopes that antismoking campaigns can communicate more effectively with one high-risk group-college student smokers.
\end{abstract}

All the "truth" campaign does is convince me that I should go outside and light up another cigarette. (Participant \#24)

... All smokers hate anti-smoking ads, whether they're good or not. They hate them because they love to smoke and hate being told not to 
NOT THE PUBLISHED VERSION; this is the author's final, peer-reviewed manuscript. The published version may be accessed by following the link in the citation at the bottom of the page.

do something. Every smoker I know has a no-smoking sign in their house to make a mockery of anti-smoking messages. (Participant \#67)

I am going to have to die from something someday, and I like smoking, so why shouldn't this be my cause of death? (Participant \#43)

These are the comments of college student smokers in response to the wide range of antismoking messages found in the media. Their anger and defiance make it imperative that researchers investigate whether these responses are isolated incidents or a widespread response. If anger and defiance are the rule rather than the exception, many of the antismoking messages that may successfully prevent young teens from starting to smoke may nevertheless be ineffective with college students who already smoke, or worse, undermine smokers' efforts to quit.

Despite the optimism that counteradvertising campaigns can be effective, comments from college students wave a warning flag that special initiatives may be needed for different audiences. Specifically, researchers must investigate whether the types of prevention efforts that can be successful with nonsmokers are either ineffective or change attitudes in the wrong direction among smokers. Using a qualitative approach to understand the realities of college student smoking, this study attempts to evaluate the effect of various sources of antismoking messages on college student smokers and nonsmokers, and to probe for insights into effective communication. It first considers the nature of the problem, social marketing campaigns, and responses predicted by risk models and psychological theories. It then organizes the data around a set of research questions and makes recommendations for the creators of antismoking messages so that their efforts achieve the greatest possible success and better serve consumers.

\section{The nature of the problem}

The Centers for Disease Control and Prevention (CDC) estimates that more than 46.2 million Americans smoke, despite the fact that smoking results in the death or disability of half of all regular users, with more than 440,000 deaths attributed to cigarette smoking each

Journal of Consumer Affairs, Vol 40, No. 2 (Winter 2006): pg. 294-323. DOI. This article is @ Wiley and permission has been granted for this version to appear in e-Publications@Marquette. Wiley does not grant permission for this article to be further copied/distributed or hosted elsewhere without the express permission from Wiley. 
year (Targeting Tobacco Use: The Nation's Leading Cause of Death, USDHHS 2004). The onset for tobacco use typically occurs during adolescence, which accounts for the majority of prevention efforts being directed at preadolescents and young teens; however, some research suggests that the onset is later for some population groups including African American women whose smoking rates continue to increase through the twenties (Moon-Howard 2003).

Smoking is a concern for all individuals, but among college students it is especially problematic. With the transition to college comes the freedom to make self-initiated choices including the decision whether or not to smoke (Emmons et al. 1998; Patterson et al. 2004). Some college students experiment with cigarettes for the first time, and many who were occasional smokers in high school become heavier smokers as they enter college (Christie-Smith 1999; Patterson et al. 2004; Schorling et al. 1994). More than $60 \%$ of college students have tried a tobacco product, $46 \%$ have done so in the past year, and 33\% are current tobacco users (Rigotti, Lee, and Wechsler 2000). Because young adults represent the youngest legal targets of tobacco industry marketing, Rigotti, Lee, and Wechsler suggest that they may need special countermarketing efforts.

Forty-four percent of young adults aged 18-25 use tobacco in the form of cigarettes, smokeless tobacco, cigars, or pipes, compared to $29 \%$ for those aged 26 and older, and $15 \%$ for those aged $12-17$ (National Household Survey on Drug Abuse, USDHHS 2001). Although the prevalence of cigarette smoking decreases with increasing levels of education, usage among college students remains a concern. Thirtythree percent of full-time college students aged 18-22 have smoked cigarettes in the past month (National Household Survey on Drug Abuse, USDHHS 2001).

Though many college students believe that they can quit smoking any time and therefore are not at risk, a longitudinal study at one university reported that over the course of four years almost $90 \%$ of daily smokers and $50 \%$ of occasional smokers continued to smoke (Wetter et al. 2004). Furthermore, $14 \%$ of occasional smokers became daily smokers and $11 \%$ of nonsmokers took up smoking. Sixty-eight percent of college students have tried to quit smoking at some time (Youth Risk Behavior Surveillance Report, USDHHS 1997). Given the

Journal of Consumer Affairs, Vol 40, No. 2 (Winter 2006): pg. 294-323. DOI. This article is (C) Wiley and permission has been granted for this version to appear in e-Publications@Marquette. Wiley does not grant permission for this article to be further copied/distributed or hosted elsewhere without the express permission from Wiley. 
tendency of college student smokers to underestimate the difficulty in quitting, special initiatives may be needed to effectively promote smoking cessation. Greater success in curbing smoking would not only benefit smokers but other members of society as well, many of whom suffer the toll of secondhand smoke and rising health care costs.

\section{Social marketing campaigns}

Given the seriousness of the health problems, a number of studies have attempted to isolate the factors that lead to smoking in hopes of creating more effective social marketing campaigns. Advertising has been singled out as a potentially powerful agent of influence, with calls for various restrictions on tobacco advertising and increased antismoking efforts (DeLorme, Kreshel, and Reid 2003). However, most studies have demonstrated only weak effects from advertising or have provided seemingly contradictory evidence.

Peer pressure, family smoking behavior, and prior beliefs have consistently been identified as more important factors in predicting smoking level among adolescents than product advertising and antismoking campaigns (DeLorme, Kreshel, and Reid 2003; Smith and Stutts 1999). Researchers for econometric studies add further support to the weak effects perspective by concluding that aggregate advertising does not stimulate consumption (Andrews and Franke 1991; Duffy 1996).

Social marketing campaigns typically attempt to discourage harmful behavior or encourage positive behavior (Andreasen 1994). Past efforts have been directed not only toward smoking prevention and cessation (Farrelly et al. 2002) but also toward a multitude of other issues including drinking (Agostinelli, Brown, and Miller 1995), drugs (Kelder et al. 2000), obesity (Vranica 2003), AIDS (Witte 1991), use of seat belts (Calkins and Zlatoper 2001), sunscreen for skin cancer prevention (Huncharek and Kupelnick 2002), and medical screening tests (Keller, Lipkus, and Rimer 2002). However, the effectiveness of social marketing campaigns is sometimes less positive than hoped for. Rotfeld (2001) notes that social marketing campaigns have the very difficult task of persuading large numbers of people to change their behavior despite the fact that they are fully aware of the consequences of their behavior and have already decided to ignore the 
risks. Furthermore, Rotfeld notes that the basic question of whether advertising can bring about behavior change often goes unasked, resulting in marketing that is "misplaced." Some campaigns are not only ineffective but also have triggered adverse effects, such as increased drinking by college students in response to antidrinking campaigns on college campuses (Wechsler et al. 2003). These adverse effects are what Pechmann and Slater (2005) call the "dark side" of social marketing campaigns.

Several recent studies have reviewed the vast literature on the effectiveness of antismoking efforts (see Agostinelli and Grube 2003, and Wakefield et al. 2003 for comprehensive evaluations). Wakefield et al. (2003) note that an already intense debate about the efficacy of antismoking themes was fueled after several states received funding from the 1998 Master Settlement Agreement (MSA) between tobacco manufacturers and attorneys general and also after several tobacco companies began to use advertising strategies to target youths via antismoking campaigns. Wakefield and her colleagues conclude that antismoking ads appear to have the most reliable, positive effects for those in preadolescence and early adolescence by preventing smoking initiation; that interactions with family and peers can reinforce, deny, or neutralize potential effects of antismoking messages; and that various types of message strategies have proven inconsistent, leaving no single "recipe" for antismoking advertising.

A number of different strategies have been used in antismoking messages aimed at adolescents including a focus on long-term health effects, short-term cosmetic effects, tobacco marketing practices, marketers as "murderers," secondhand smoke, negative social consequences, and attractiveness of nonsmokers (Pechmann and Goldberg 1998; Stutts, Smith, and Zank 2003). In their review of the research, Agostinelli and Grube (2003) evaluated studies that addressed counteradvertising message content and the psychological mediators involved, and prior smoking experience, among other factors. Regarding message content, Agostinelli and Grube concluded that certain outcome expectancies, such as beliefs about the potential gains and losses from smoking such as the likelihood of developing lung cancer, effectively predict smoking behavior but are ineffective messages for counteradvertising content regardless of whether the messages target short-term or long-term health effects (Goldman and 
Glantz 1998) and regardless of the type of negative consequences, such as unattractiveness, death, and disease (Pechmann and Goldberg 1998). Similarly, normative beliefs-perceived approval or disapproval from others and beliefs about the behavior of others-effectively predicted smoking behavior but failed as counteradvertising messages (Morgan and Grube 1994). The normative approach generated executions such as "kissing a smoker is like licking an ashtray" (Goldman and Glantz 1998) but was deemed ineffective because, among other things, it did not consider the smoking status of the message recipient.

The theme of manipulation by tobacco companies held much hope as a persuasive message; however, it too received mixed results-effective in some studies (Goldman and Glantz 1998) and ineffective in others (Pechmann and Goldberg 1998). Message strategies that were the most effective in preventing smoking among 7th- and 10th-grade nonsmokers bolstered their intentions not to smoke and included themes of endangering family, portraying smokers' negative life circumstances, and providing a role model for refusal skills (Pechmann et al. 2003). Message strategy effectiveness among adolescents has also been shown to vary by gender with cosmetic fear appeals more effective for males and long-term health fear appeals more effective among females (Smith and Stutts 2003).

When considering prior smoking experience, Agostinelli and Grube (2003) noted that smokers often process tobacco-related information in a biased, self-protective direction. Smokers are overly optimistic in judging the health-related consequences to smoking (Reppucci et al. 1991; Weinstein 1998) and are more likely than nonsmokers to believe the positive attributes of smoking (e.g., smoking makes them more popular and attractive) (DiFranza et al. 1991). Given the selective perception processes (Chassin, Presson, and Sherman 1984), factual, nonjudgmental approaches are recommended (McKenna and Williams 1993), as well as messages with appealing style elements such as humor and music (Grube, Madden, and Friese 1996).

One body of research that sheds light upon ineffective campaigns addresses "boomerang effects," which refer to behavior responses opposite to what is called for (see Ringold 2002 for a 
comprehensive review of the literature in response to health-related interventions). Boomerang effects have long been associated with a multitude of countermarketing efforts including the previously noted increase in alcohol consumption among college students in response to antidrinking campaigns (Wechsler et al. 2003), increases in alcohol consumption after raising the legal drinking age (Engs and Hanson 1989), increased desire to smoke in response to government warning

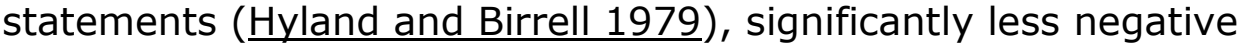
attitudes about amphetamine and barbiturate use after exposure to warnings against use of the drugs (Feingold and Knapp 1977), and increased attraction to violent films after exposure to the warnings adopted by U.S. television networks (Bushman and Stack 1996), to name a few. Boomerang effects are not a given, for Mackinnon and Lapin (1998) were unable to replicate these effects from alcohol warnings reported by Snyder and Blood (1992). However, the substantial number of studies that do claim boomerang effects bears serious consideration.

Such effects are not limited to the United States as various boomerang responses have been reported abroad including retaliatory "smoke-ins" in the United Kingdom in response to attempts to restrict smoking (King 2003) and the placing of stickers to cover warning labels on packages of cigarettes in the United Kingdom, Spain, France, and Germany. Stickers carry slogans such as "Smoke in peace" and "Tomorrow, you could get hit by a bus" and are sold in various European cities and on the Internet (Bhatti 2004).

\section{Responses predicted by risk models}

A review of current risk models provides some insights into responses to antismoking messages since many campaigns attempt to portray smokers as people at risk, either physically or socially. The Extended Parallel Process Model (EPPM) (Witte 1994) predicts that when exposed to a fear appeal, people are motivated to either control the danger by lessening their at-risk behavior or control the fear often through denial. In order for people to control the danger, four conditions must be met. They must (1) feel that the threat is severe (e.g., that smoking leads to disease or death), (2) feel vulnerable to the threat (e.g., that the consequences of smoking will affect them 
personally), (3) feel capable of changing their at-risk behavior (e.g., quit smoking), and (4) perceive the behavior change as effective in averting the threat (e.g., that quitting smoking effectively eliminates the risk). When all four conditions are high, they are more likely to avert the danger by modifying behavior than when only some conditions are met. For example, most smokers know that the threat is severe if they continue to smoke over a lifetime; however, many believe they will quit before they are at risk. Thus, they lack the feeling of vulnerability necessary for behavior change.

The model also predicts a second behavior path-one motivated by fear. If people are too fearful, they expend their energy controlling the fear instead of reducing the danger by getting out of harm's way. When a vulnerable person feels threatened but lacks the efficacy to bring about change (e.g., the smoker who is worried about health and has tried to quit but failed), fear is the end result. Fear in turn can trigger denial, aggression, and the likelihood of riskier behavior.

Wolburg (2001) extended the EPPM with the Integrated Risk Perception Model, which predicts that people not only engage in fear control if they feel they lack the efficacy to make the change but also if they perceive that the costs of quitting outweigh the benefits. If they perceive that either the benefits of smoking are too meaningful or the costs of quitting are too great, they lack the desire to quit. The individual who is unwilling to act is likely to react with anger, defiance, denial, or other boomerang effects-just as is the person who is unable to act.

\section{Responses predicted by psychological theories}

Treatment for addictive behavior (e.g., smoking, alcohol dependence, and drug abuse) is often conducted in person by trained specialists rather than through mass media messages such as public service announcements (PSAs). However, many of the strategies used in clinical settings are relevant for PSA development.

Psychologists have concluded that responses such as defensiveness, denial, resistance, and combativeness are neither personality traits nor evidence of personality disorders but instead are predictable reactions created by certain communication strategies 
(Miller and Rollnick 1991). They believe that "psychological reactance" is a predictable pattern that occurs when individuals believe their personal freedom is being reduced or threatened (Brehm 1966; Brehm and Brehm 1981). When people are confronted with their undesirable behavior (smoking, drinking, obesity, etc.) or told that they "must, should, or cannot" do something, they are likely to become argumentative, deny the accuracy of the charge, and assert their personal freedom (Miller and Rollnick 1991). The theory predicts that when people perceive a threat to personal freedom, they find the addictive behavior all the more attractive.

In order to quit smoking, certain "stages of change" must occur (Prochaska and DiClememte 1982), which include contemplation (deciding whether the behavior is a problem or not), determination (deciding to take action with an acceptable strategy), action (doing something that effectively brings about change), maintenance (sustaining the change), and relapse (returning to the addictive behavior, which is undesirable but not unexpected). Individuals in relapse sometimes respond with renewed contemplation and determination and begin the cycle again. Prochaska and DiClememte found that smokers went through the complete set of stages an average of four times before finally quitting.

\section{Method}

With this knowledge base, a qualitative research study was designed to investigate the impact of antismoking messages upon both smokers and nonsmokers and to extend the research to college students-a group that is not usually the primary target market for most antismoking messages but is nevertheless a high-risk group that is heavily exposed to them. The study attempts to answer the following research questions:

RQ1: What general responses do college students have to antismoking messages found in the media?

RQ2: Among college students, do smokers and nonsmokers differ in their responses?

Journal of Consumer Affairs, Vol 40, No. 2 (Winter 2006): pg. 294-323. DOI. This article is (C) Wiley and permission has been granted for this version to appear in e-Publications@Marquette. Wiley does not grant permission for this article to be further copied/distributed or hosted elsewhere without the express permission from Wiley. 
NOT THE PUBLISHED VERSION; this is the author's final, peer-reviewed manuscript. The published version may be accessed by following the link in the citation at the bottom of the page.

RQ3: Among college students, do antismoking messages from the tobacco industry elicit different responses than those from nonprofit organizations?

RQ4: What influence (if any) do antismoking messages have upon college students' decisions to smoke, not smoke, quit smoking, not quit, etc.?

RQ5: What insights do current risk models and psychological theories provide for understanding the responses of smokers and nonsmokers?

\section{Stage 1}

Advertising and public relations students in an upper-level undergraduate research course taught by the researcher conducted 110 initial interviews in Stage 1 of a two-stage process. Stage 1 served as a preliminary part of the project in order to familiarize and ground the researcher with a broad range of ideas about students' responses to current antismoking messages. These interviews were part of a required assignment designed to teach students to conduct depth interviews. Each of the 55 students in the class interviewed two other college student volunteers as participants-one who smokes and one who does not. Using smoking status categories developed by the CDC's National Center for Health Statistics (USDHHS 1993), a nonsmoker was defined as a person who either has never smoked at all or has smoked less than 100 total cigarettes in his/her life and none in the past 30 days. A smoker was defined as a person who currently smokes, has smoked more than 100 total cigarettes in his/her life, and has smoked at least 10 in the past 30 days. Students were taught basic interviewing techniques and were provided with a list of required questions to ask participants; however, they were also allowed to ask follow-up questions that they deemed would offer insights. Students were instructed to tape-record the interviews and turn in a summary of findings in addition to transcripts of the interview.

Participants were first asked for their responses in general to antismoking messages found in the media. This was done not only to provide a broad starting point for the interview (McCracken 1988) but also to allow the participants to draw from their own memories to select campaigns that they found worthy of comment. Second, they 
NOT THE PUBLISHED VERSION; this is the author's final, peer-reviewed manuscript. The published version may be accessed by following the link in the citation at the bottom of the page.

were asked their reaction to specific magazine ads shown to them: an ad from the "truth" campaign that used a two-page spread (Figures 1 and 2) and an industry ad from Lorillard (Figure 3).

\section{Figure 1.}

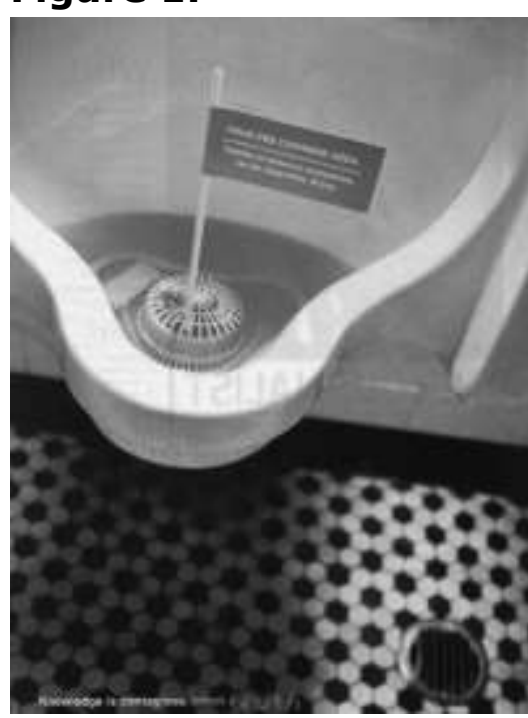

Message from American Legacy Foundation's "the truth" Campaign, page 1 of a 2page spread

\section{Figure 2.}

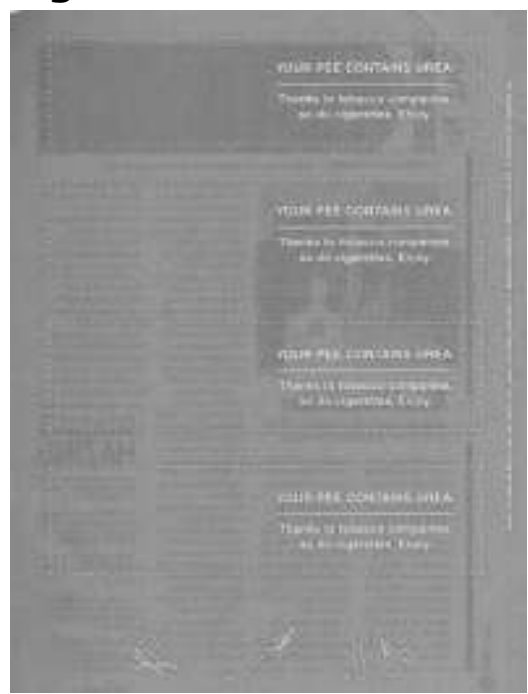

Message from American Legacy Foundation's "the truth" Campaign, page 2 of a 2page spread 


\section{Figure 3.}

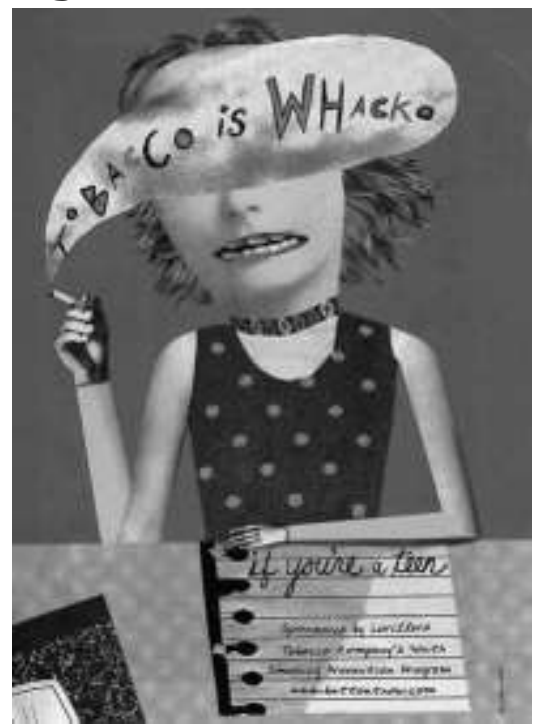

Message from Lorillard Tobacco Company's Youth Smoking Prevention Program

The "truth" ad was part of a nationwide countermarketing initiative created by the American Legacy Foundation and funded by the MSA (Healton 2001). Ads in the series attempt to inform teens about tobacco and the industry's marketing practices using "edgy" youths on the cutting edge of trends, which are supported by promotional items and the Web site located at www.thetruth.com (Farrelly et al. 2002). The particular ad in this study was one that used shock value to highlight the ingredients in cigarettes. It stated, "Your pee contains urea. Thanks to tobacco companies, so do cigarettes. Enjoy." The "truth" ad delivered the main message on one page and included flags to be cut out on the second page, which readers could place in urinals as warnings for others to see.

The Lorillard ad was part of a campaign that included a Web site at www.buttoutnow and print and television ads, which delivered the line "Tobacco is Whacko-if you're a teen." The campaign was part of Lorillard's Youth Smoking Prevention Program, which began in 1999 and later expanded to include a parent education program (Lorillard Tobacco Company 2005). The ad used in this study showed a cartoon figure of a girl who delivered the "tobacco is whacko" line. Both the Lorillard and "truth" ad were chosen because they represented antismoking messages that were part of major campaigns found in magazines that were seen by college students at the time. 
NOT THE PUBLISHED VERSION; this is the author's final, peer-reviewed manuscript. The published version may be accessed by following the link in the citation at the bottom of the page.

Third and last, the participants were asked what role (if any) antismoking messages have in shaping their decisions about smoking.

\section{Stage 2}

The researcher conducted the second stage of the project, which included analyzing the transcripts and summaries of interviews conducted by students in Stage 1, soliciting and analyzing 25 student essays on responses to antismoking campaigns, and conducting and analyzing 15 depth interviews among college student volunteers, each lasting about an hour. Essay writers were students in an advertising media planning class, who selected the exercise from one of three class options for extra credit. They were asked to classify themselves as a smoker or nonsmoker according to the earlier definitions, to write their reactions to antismoking messages that they encountered in the mass media, and to comment on any that stood out. Names of all students who turned in extra credit were kept on a separate list; no name was attached to any essay in order to maintain anonymity and to maximize the likelihood of generating candid, unbiased comments.

Participants for depth interviews were recruited from fliers posted on campus. They were asked the same questions as the 110 participants in the initial stage and were shown the same set of ads. The essays and depth interviews in Stage 2 were conducted to accomplish three goals: (1) to demonstrate whether the themes identified in Stage 1 would reemerge under different conditions and with a more experienced researcher, (2) to provide an opportunity for greater exploration and follow-up of themes, (3) and to offer an opportunity for new themes to emerge (Fontana and Frey 1994). Furthermore, the comparative assessment of more than one form of evidence allowed for triangulation (Lindloff 1995). No incentives were given to participants in Stage 1; however, each essay writer received five points added to a test grade, and each participant for the depth interviews received $\$ 10$. Human subject approval was granted by the university's institutional review board. Although the 25 students who wrote essays were primarily advertising students, most of the 110 students who participated in Stage 1 and the 15 students who participated in depth interviews were students from other colleges within the university.

Journal of Consumer Affairs, Vol 40, No. 2 (Winter 2006): pg. 294-323. DOI. This article is (c) Wiley and permission has been granted for this version to appear in e-Publications@Marquette. Wiley does not grant permission for this article to be further copied/distributed or hosted elsewhere without the express permission from Wiley. 
All data were analyzed using analytic induction and the constant comparison method to determine common themes (Glaser and Strauss 1967). By the final analysis of the data from the two stages, no new themes emerged, which indicated that the interviews were sufficient in reaching the point of redundancy (Taylor 1994). Because the findings in Stages 1 and 2 were extremely consistent, they were combined to avoid repetition. The consistency of findings between stages suggests that the behavior patterns reported are highly robust.

\section{Findings}

RQ1 asked how students respond in general to antismoking messages that they find in the mass media. Of the 150 participants in total, no one was unaware of antismoking campaigns and all had opinions, which are organized below. RQ2 asked if responses differed among smokers and nonsmokers. Since distinct differences emerged between the two groups, their comments are treated separately. Smokers' responses are offered in greater detail because smokers not only pose a more significant health risk but also hold more negative opinions toward antismoking messages compared to nonsmokers.

\section{Smokers' Responses to Ads in General}

\section{Annoying and Ineffective}

Smokers regarded antismoking messages as "a daily dose of guilt" that they find annoying and ineffective at changing behavior. Smokers recognize that smoking is harmful but say they require more than an ad to change their behavior. What would in fact change their behavior remains unclear-only that it must be more compelling than an ad.

There isn't an ad out there that would get me to quit. A smoker who isn't ready to quit won't do so from an ad. (\#45)

They're dumb (anti-smoking ads). Nobody wants to see 1000 body bags on TV. I change the channel or ignore them. Or else I laugh. (\#81) 
NOT THE PUBLISHED VERSION; this is the author's final, peer-reviewed manuscript. The published version may be accessed by following the link in the citation at the bottom of the page.

Quit? Hell, no! This tobacco's got me hooked. The ads might work for someone who smokes Kools or something, but I'm a Marlboro man for life. (\#19)

Some participants found antismoking messages ineffective because they deny that smoking is cool. Aside from the harmful effects, smoking is still considered cool.

I laughed at the ads that say smoking isn't cool because it's very cool, it looks cool-it's glorified in movies. It's cool no matter how many people tell you otherwise. The horrible effect that it has on you is something else ... but there's no doubt it's cool. (\#112)

\section{No New Information}

Many smokers are insulted that the messages attempt to communicate information that is already common knowledge. The problem is not lack of information but lack of ability to deal with an addictive substance, and hearing the risks restated is not only annoying but also condescending.

You would have to be a moron to not know that it kills. (\#43)

I don't need someone reminding me that I am going to die if I continue to smoke cigarettes in this day and age. It's common knowledge, and I can read it on the side of the box. (\#19)

Most people who smoke already know all the risks but are too addicted to the tobacco to stop smoking.... Quitting is something that you just have to want to do. I plan on quitting sometime. I just don't want to right now. (\#9)

\section{Defiant Reactions to Limits on Freedom}

Perhaps the most intense response is the anger, resentment, and defiance that smokers exhibited in response to perceived attempts to interfere with their lives and limit their freedom. Smokers' responses repeatedly included some variation on the theme of "the only thing those ads do is make me want to light up a smoke." They said:

Journal of Consumer Affairs, Vol 40, No. 2 (Winter 2006): pg. 294-323. DOI. This article is (c) Wiley and permission has been granted for this version to appear in e-Publications@Marquette. Wiley does not grant permission for this article to be further copied/distributed or hosted elsewhere without the express permission from Wiley. 
NOT THE PUBLISHED VERSION; this is the author's final, peer-reviewed manuscript. The published version may be accessed by following the link in the citation at the bottom of the page.

These are the kind of ads where people try to get in your face about something I choose to do. It's just annoying and makes me want to smoke more. It is really none of their business if I smoke or not. (\#37)

I can't turn on the TV without those frickin' stupid kids being in my face about smoking ... they act like they are better people just because they don't smoke. (\#17)

Let me tell you something. All smokers hate anti-smoking ads, whether they're good or not. They hate them because they love to smoke and hate being told not to do something.... (\#67)

Some participants use antismoking messages as a visual cue or reminder to light up. Others showed outright defiance, such as the following participants, who commented that smoking a cigarette allows them to play the role of rebel and make a statement.

Last summer on my way home from work, the "truth" mobile pulled right up next to me at a stoplight, and I couldn't believe it. I had smoked my last cigarette on my way to the car, and all I wanted to do was have a cigarette. I had no reasoning behind that ... but somewhere deep down maybe subconsciously, even though it is a bit childish, all I wanted to do was smoke. (\#112)

... It's like my little way of saying, "take that. I'm going to do it anyway." I'm being the bully, the rebel that I never was in high school or grade school. (\#140)

\section{Denial}

In addition to expressing defiance, many smokers refuse to admit the risks involved. Those who did acknowledge the risks often denied their severity, minimized their importance, or simply laughed them off. Many were confident that they would successfully quit before the risks became an issue.

Nothing bad will happen to me now so why bother? Cigarettes serve a purpose by giving pleasure. No one wants to live forever. (\#45)

I am going to have to die from something someday, and I like smoking, so why shouldn't this be my cause of death? (\#43)

Journal of Consumer Affairs, Vol 40, No. 2 (Winter 2006): pg. 294-323. DOI. This article is (c) Wiley and permission has been granted for this version to appear in e-Publications@Marquette. Wiley does not grant permission for this article to be further copied/distributed or hosted elsewhere without the express permission from Wiley. 
NOT THE PUBLISHED VERSION; this is the author's final, peer-reviewed manuscript. The published version may be accessed by following the link in the citation at the bottom of the page.

You put bad stuff in your mouth everyday. This isn't any different. Bad things when used in moderation won't hurt you. (\#59)

\section{Cost/Benefit Analysis}

Instead of denying the risks, other smokers simply justified smoking on the basis of the pleasure it provides. They felt that the rewards and benefits of smoking were greater than the costs.

I like it because if I am having a really hard day and I feel like I am going to pull my hair out, I can take a break, go outside, and have a cigarette, and suddenly things aren't so bad. It's my way of taking time for myself, taking a step back, and if I did not have this, I would go insane. (\#57)

When people start to smoke, they accept the danger for the feeling they get or the relief of stress. I knew all of the bad things about smoking before I started.... It just came with the scene and now I am hooked. But hooked because I don't want to quit. I like being a smoker right now .... (\#13)

One smoker articulated the special meaning that smoking provides by naming certain cigarettes of the day. He also spoke to the feeling of deprivation he would experience if he had to give up smoking completely.

... there are too many cigarettes I enjoy. If I am out fishing, I really like having a cigarette.... And if I quit, I would miss that. I love that cigarette. I love the "going fishing cigarette".... My freshman year, I absolutely loved the cigarette in the middle of winter after walking my girlfriend home to the residence hall. I would walk back [to the residence hall] and have a cigarette on the way back. I loved it. I thought it was nice. It was relaxing. If someone said to me, give up smoking while you're walking to class, I'm sure I could do that. I really don't need that cigarette. But to ask me to give up smoking completely-there are just too many cigarette moments that I really enjoy. (\#112)

\section{Entitlement to Small Vices}

One way that smokers reject the "daily dose of guilt" and defend their right to smoke is through the belief that people are entitled to

Journal of Consumer Affairs, Vol 40, No. 2 (Winter 2006): pg. 294-323. DOI. This article is (c) Wiley and permission has been granted for this version to appear in e-Publications@Marquette. Wiley does not grant permission for this article to be further copied/distributed or hosted elsewhere without the express permission from Wiley. 
simple pleasures in life, even small vices. This reasoning is bolstered by comparing smoking against potentially worse vices. The following comment shows a thinly disguised level of hostility aimed at antismoking messages.

This is something I like doing. I don't do drugs. I don't drink excessively. It's such a clichéd excuse. Of all the vices, can't I have my one little cigarette? That's what it comes down to.... All I'm doing is smoking. I'm not doing heavy drugs or robbing banks or murdering people. This is as bad as I get. Let me have my cigarette. Let me just enjoy this. (\#112)

One reason students feel entitled to a vice is that they believe that smoking is harmful only to themselves, unlike other vices such as drinking, which can have detrimental effects on others.

.... I guess there are a few effects to other people through secondhand smoke, but I feel I'm doing more damage to myself. I'm OK with that because that's my big vice. Don't touch my vice. But with drinking and driving, that's potentially causing serious harm to yourself and to countless others. That's where the big difference is.... (\#140)

Most student smokers did not see themselves contributing to the problem of secondhand smoke because restrictions prevent smoking in public buildings, residence halls, etc. Since smoking is permitted only outdoors, in smoking sections of restaurants, and in bars, they feel that nonsmokers can effectively avoid exposure from cigarette smoke. Their main concern was within homes where parents expose children to smoke, which does not generally apply to them at this point in their lives.

\section{Third-Person Effects}

Many smokers attributed a third-person effect (Neuwirth, Frederick, and Mayo 2002) to the messages. They insisted that the ads would not change their own behavior but may help younger people who have not yet started to smoke. Some commented on the timing and the strategies they think work best on others and speculated that if those messages were prevalent at the time they began smoking, their choice might have been different. 
The damage is already done for us smokers, but this might help keep kids away from it. (\#19)

The only ones that I think work show people smoking in a group. Kind of like when it's pressured on somebody and then that one person in the group says no. If I had seen messages like those at the time that I started smoking, I might have said, no-no thank you. I was in that situation when my friend offered it to me and I had every opportunity to say no, but when I was young I really didn't see any example of that in the media against smoking. (\#139)

\section{Nonsmokers' Responses to Ads in General}

\section{Pleased and Supportive}

When nonsmokers were questioned about their reactions to antismoking messages, it came as no surprise that they lacked the annoyance, defiance, and denial of smokers and were generally enthusiastic. They enjoyed the scare tactics and judgmental depictions of smokers, often with great satisfaction that someone took their side and spoke up for their rights They no longer felt they were a minority and believed that the decision not to smoke gained legitimacy.

I think it's about time someone took responsibility for the deadly addiction that kills so many people. (\#42)

Smokers need to know how non-smokers really feel.... I find most smokers to be rude and inconsiderate, while non-smokers politely suffer or move out of the smoker's way. An ad true to my heart would be one showing a non-smoker presenting the smoker with a bill for the dry cleaning or doctor's expenses for asthma medication.... (\#134)

One area in which nonsmokers agreed with smokers was through third-person effects. Nonsmokers saw strong potential to prevent teens from starting to smoke, regardless of whether they successfully altered the behavior of existing smokers.

Journal of Consumer Affairs, Vol 40, No. 2 (Winter 2006): pg. 294-323. DOI. This article is (c) Wiley and permission has been granted for this version to appear in e-Publications@Marquette. Wiley does not grant permission for this article to be further copied/distributed or hosted elsewhere without the express permission from Wiley. 


\section{Smokers' Responses to the "truth" Ad}

RQ3 asked if responses among college students differed between ads from nonprofit organizations and industry ads. When shown the "truth" ad ("your pee contains urea ...,"), smokers' responses were consistently different from those for the Lorillard ad (tobacco is whacko). Smokers intensely disliked both campaigns but for different reasons. Criticism of the "truth" campaign centered upon its heavy-handedness, whereas criticism of the Lorillard campaign was based on its insincerity. In comparison to antismoking messages in general, smokers' responses to the "truth" ad were more specific. While the general response categories noted before still applied, several new ones emerged.

\section{Counterarguing the Logic}

Smokers usually reacted negatively to the "truth" ad with descriptions of "stupid, hilarious, worthless, gross, obnoxious, funny, and unpleasant." Smokers also analyzed the internal logic, arguing that containing urea is not the same as making cigarettes out of pee. Those who found the message flawed, deceptive, or manipulative, felt entitled to reject the entire message. Furthermore, they were more likely to vilify the sender (the creators of the "truth" campaign) rather than the tobacco companies.

My pee contains sugar, too but that doesn't mean I'm not going to eat candy bars. (\#57)

What the hell is urea? People who simply do not like smoking create the entire controversy. It is unfair to pinpoint just the tobacco companies, for there are many other industries that are detrimental to one's health, such as cell phones, alcohol, and Coke, which erodes the stomach. (\#27)

They'll go to any means to stop people from smoking. I bet they even lied on some of those ads just to get their point across. The tobacco companies don't make cigarettes out of pee. (\#107) 
NOT THE PUBLISHED VERSION; this is the author's final, peer-reviewed manuscript. The published version may be accessed by following the link in the citation at the bottom of the page.

\section{Desensitization}

Some smokers expressed positive reactions to the "truth" campaign for its raw and honest effort that made them confront their behavior. They felt that the creators of the campaign were the only ones who really cared. Some said they needed more repetitions of the message than the campaign delivered, whereas others said they became desensitized over time and eventually learned to tune out the messages, even though they were initially thought provoking. This inevitably points to the difficulty in anticipating what level of frequency is optimal for consumers.

I thought about those commercials a lot. They made me think, you know. I even quit for a couple days after I first saw them. Then I bought less packs, but when the messages wore off, I started smoking a pack a day again. I didn't have those commercials to remind me. (\#27)

The first time I saw the ads, I was impressed. Now the campaigns are too heavy. It's just annoying now. It's less effective on me because whenever it comes on TV, I just zone out or change the channel. It's on all the time, and I don't want to hear that smoking is killing me every second. (\#39)

\section{Fear as an Ineffective Motivator}

Smokers were aware that most anitsmoking messages were based on scare tactics; however, they generally found the messages ineffective.

It isn't scary enough to shake your core values. Even the Marlboro model's brother-he lost his brother to lung cancer. This is an actual situation where people can relate. It doesn't do a damn thing for me. Who cares? Not me or any other person who smokes. That's for sure. (\#69)

My parents have been threatening to take my tuition away for years, and that was not enough to make me quit, so why would the ad? (\#25)

One participant elaborated on the failure of real situations to elicit fear, which he felt should be more powerful than ads. 
I lopped part of my finger off and had to go to the hospital to have it sewn back and there was a guy sitting next to me with a tracheotomy.... It was frightening because he could take that little plastic pipe deally out and there was a hole there. I was thinking about it, and I was like "that's awful!" But when I left the hospital, I went out and had a cigarette. It's the proof right there that scare tactics don't work.... Even when it was pushed in my face-this man with a gaping hole in his neck-it didn't make a difference to me. That's the case with a lot of smokers. (\#112)

\section{Extreme Defiance}

Though defiance and anger were responses to antismoking messages in general, the intensity of the defiance toward the "truth" ad was particularly strong. Several indicated how they would respond if anyone took up the ad's call to action to place a flag in a urinal.

.... If one of my friends gave me a flag, I would throw it out. That person wouldn't be my friend anymore. (\#87)

I would pee on the sign in the urinal and light up upon departure from the bathroom. (\#27)

The advertisers thought they were really being smart when they made it ... as if anyone is really going to put these little fucking flags up anywhere. That's just a waste of a page. (\#49)

\section{Nonsmokers' Responses to the "truth" Ad}

\section{Smoking as Inexplicable Behavior}

In response to the "truth" ad, nonsmokers offered many comments that showed their inability to understand how people could continue to smoke, given the persuasiveness of the messages and the health risks.

I don't see how people could have one more cigarette after seeing an ad like that. What is wrong with people? Why would people want to inhale a chemical that's in their bodily waste? (\#14)

Journal of Consumer Affairs, Vol 40, No. 2 (Winter 2006): pg. 294-323. DOI. This article is (c) Wiley and permission has been granted for this version to appear in e-Publications@Marquette. Wiley does not grant permission for this article to be further copied/distributed or hosted elsewhere without the express permission from Wiley. 
Who would be dumb enough to smoke urea? I wouldn't ever smoke, but if I did, this ad would probably make me want to stop.... I respect the intelligence of the creators. I'd listen to what they were saying. (\#86)

Are you serious? Smoking takes years off your life, stinks, hurts and quitting is the only way. I cannot understand why people smoke-why they bother when they know how gross it makes them look. It's grotesque. (\#36)

\section{Evaluations of Strategy}

Many nonsmokers overestimated the effectiveness of the ad. They found it provocative and on target strategically.

If I smoked, it would really make me think twice. I would be so disgusted by this fact that I would try to stop smoking right away. (\#88)

Wow. This is an excellent ad.... If I were to walk into a bathroom and see that in the stall or urinal, I would be a bit freaked out.... It really gets the message across that smoking is bad for you not only because of the consequences but because of its contents. (\#28)

A minority of nonsmokers doubted that this ad would convince smokers to quit and suggested that the money could be better spent on 1-800 quit lines and other programs. Quite accurately, they identified the problems most smokers had with the ad.

.... "truth" ads insult smokers. That just makes matters worse. I think that would just make them want to smoke more. (\#16)

It's a well-done ad, but I think the "truth" ads bank on the hope that people will make the connection between urine and cigarettes. It's a bit dishonest. (\#74)

\section{Legitimizing nonsmoking behavior}

Perhaps the most interesting response among nonsmokers is that the ad reinforces the decision not to smoke and legitimizes nonsmoking behavior. Nonsmokers no longer have to feel "uncool." 
It enhances my decision to not smoke. Smoking always made me sick and smokers never understand why. Well, this is the perfect example. I knew before this interview that I would never touch a cigarette. This ad is just like frosting on the cake. (\#48)

After I see ads like this, I thank God that I wasn't stupid enough to start smoking. (\#12)

\section{Responses to the Lorillard Ad}

\section{A Disguised Prosmoking Ad}

The Tobacco is Whacko ad invited retaliation among smokers, just as the "truth" ad did. Comments included, "If I were a teen, I would smoke just to rebel against this ad," and "If I saw this in the hall at school I would probably laugh at it, rip it off the wall, or draw faces on it." However, the harshest criticism was that the ad is a thinly disguised prosmoking message. This response was consistent among smokers and nonsmokers.

It makes me think of "whacky tobaccy," which is another name for pot. They're encouraging teens to smoke pot. Their website "buttoutnow" just makes me think of mooning people, not of smoking. (\#35)

This may be the dumbest anti-smoking ad I have ever seen. This looks like one of those stupid ads in teen magazines that they use to try and sell you a product, not prevent you from using one. This makes smoking look like a joke instead of a problem. (\#17)

The qualifier on the Tobacco is Whacko ad, "if you're a teen," also received close scrutiny. Most felt it actually promoted smoking at a later age.

Tobacco is Whacko ... if you're a teen? But it is not whacko if you are 20? (\#16)

\section{Insincere Efforts}

Despite using tobacco products, smokers were highly critical of the tobacco industry, which suggests that vilifying the industry does

Journal of Consumer Affairs, Vol 40, No. 2 (Winter 2006): pg. 294-323. DOI. This article is (c) Wiley and permission has been granted for this version to appear in e-Publications@Marquette. Wiley does not grant permission for this article to be further copied/distributed or hosted elsewhere without the express permission from Wiley. 
little to deter smoking. Once they noted that the ad originated from a tobacco company, they offered scathing criticisms for what they believed were insincere efforts at discouraging teen smoking. Many students saw the ad as a blatant public relations effort.

If the company doing this ad really wanted it to work, they would have researched the way teens talk. Then they would have found out that no kid is walking around saying that something is whacko. (\#67)

This ad just screams we are doing this because we have to. It's like don't use our product ... wink, wink, wink. (\#35)

Nonsmokers found the ad equally ineffective as a persuader, one that begs for defiance and one that sends a prosmoking message. Neither the qualifier "if you're a teen" nor the perceived insincerity was lost on nonsmokers.

It's the cigarette company's job to sell cigarettes, not advocate against themselves.... They are not trying to stop people from smoking. That's why their ad looks like a big joke. (\#9)

\section{Decisions about Smoking}

\section{Smokers}

RQ4 asked whether antismoking ads played a role in their decisions about smoking. Given how ineffective most smokers find the antismoking campaigns, it comes as no surprise that most said that the messages have little to do with their decision. Some intended to continue smoking, whereas others planned to quit at a later time, although the longer they wait the more difficult it is to successfully quit.

Honestly, I will probably continue to smoke until something bad happens to someone I know. As for now, the amount I smoke will not hurt me. Smoking is not harmful in moderation. (\#49)

Another group of smokers admitted they wanted to quit now, but they believe they are unable to fight the addiction. Very few give

Journal of Consumer Affairs, Vol 40, No. 2 (Winter 2006): pg. 294-323. DOI. This article is @ Wiley and permission has been granted for this version to appear in e-Publications@Marquette. Wiley does not grant permission for this article to be further copied/distributed or hosted elsewhere without the express permission from Wiley. 
credit to ads for changing behavior, and they point to the difficulty in quitting despite the messages.

I would love to quit smoking. I think most people who do want to quit-it's expensive, you can't breathe, it ruins your life-but it's hard to quit. I've tried many times before. (\#35)

The smokers who felt that campaigns could be effective generally argued for a different strategy-one that is less judgmental, more caring of the individual, and more supportive of the difficulty of giving up smoking.

The only anti-smoking ads I believe have a powerful message are ones that ran about four years ago. The tagline was "Never Quit Quitting." It's giving support to a group of people who need support, who need to hear that just because you quit for the 15th time and it didn't work doesn't mean you shouldn't try a 16th time. I think that is really the only group that can truly be saved by advertising. That's the best way ... they need to hear somebody tell them, "keep up the good work." (\#112)

\section{Nonsmokers}

Because nonsmokers already refrain from smoking, the antismoking messages simply served to reinforce the decision that they already made. Yet, the fact that the messages strengthen their resolve may play a significant role in keeping them from changing their behavior in the future. Given the concerns that some smokers are delaying the onset-especially subgroups such as African American women-ads that bolster college students' decision not to start smoking can be valuable to the total effort.

\section{Insights from Risk Models and Psychological Theories}

RQ5 asked what insights can be gained from current risk models and psychological theories in order to develop more effective antismoking messages. The risk models predict that smokers who feel at risk but are unable or unwilling to quit due to the perceived benefits of smoking are prime candidates for fear control. Fear control can include indignation, defensiveness, defiance, resentment, denial, 
rationalization, and the desire for retaliation-all of which were demonstrated by the smokers' responses in this study.

Psychological theories provide further insights. Reactance theory predicts that when smoking behavior is condemned and smokers are told they should quit or otherwise modify their behavior, they are likely to feel threatened, become argumentative, deny the accuracy of the charge, assert their personal freedom, and "dig their heels in" deeper. All these responses are evident in this study as smokers defiantly expressed the desire to light up, counterargued the logic and accuracy of the ads, and asserted their freedom by defending their entitlement to small vices. Psychologists further predict that smokers must go through various stages in order to quit.

The students' boomerang responses are quite predictable on the basis of risk models and reactance theory. Though it is beyond the scope of the study to establish a cause and effect relationship between smokers' responses and fear or threats to personal freedom, there is ample reason to further investigate these possibilities. In the meantime, these findings should alert researchers and creators of public service campaigns to the reality that campaigns that impose restrictions on freedom or induce fear without also increasing selfefficacy are likely to be ineffective.

\section{Conclusions}

This study provides evidence that the antismoking campaigns designed to prevent adolescents from smoking send the wrong message to college student smokers. Although they reinforce nonsmokers' decisions, at best they only motivate a minority of smokers to quit and at worst they appear to trigger boomerang effects including defiance and desire for retaliation.

The intensity of nonsmokers' responses provides several insights into the gulf that separates them from smokers. Nonsmokers are generally unable to understand the appeal of smoking, and they hold greater expectations for the efficacy of the current antismoking messages. If many of the people who create and implement campaigns are nonsmokers who share these beliefs, they may not fully

Journal of Consumer Affairs, Vol 40, No. 2 (Winter 2006): pg. 294-323. DOI. This article is @ Wiley and permission has been granted for this version to appear in e-Publications@Marquette. Wiley does not grant permission for this article to be further copied/distributed or hosted elsewhere without the express permission from Wiley. 
understand the smokers' perspective, which might hamper their ability to create messages that resonate well.

Smokers' denial, defensiveness, and rationalizations get in the way of sincere contemplation of a healthier lifestyle. Though the hostile defiance and the desire to light up in response to messages may not lead to actual increases in smoking, these maladaptive reactions strengthen the resolve to smoke and clearly do nothing to decrease the levels of smoking. The following sections address strategies to avoid boomerang responses.

\section{Stages of Change}

Smokers typically go through various stages before they successfully quit. Not only must they contemplate the behavior and decide that it is in fact problematic but also they must decide upon a strategy, follow through with action, and maintain that change; otherwise, they will relapse (Prochaska and DiClememte 1982). Developers of PSAs should recognize that no single messages is going to carry the smoker through each stage of the process and should consider creating messages for different stages. Many current messages fit the contemplation stage by trying to convince smokers to quit, often by portraying smoking as problematic, harmful behavior that will lead to unwanted physical or social consequences. However, many smokers find these messages confrontational and judgmental (e.g., your pee contains urea) or insulting (e.g., tobacco is whacko). Perhaps a better way to assist smokers in the contemplation stage is provide thought-provoking ideas but without the blame, criticism, insult, or judgment that can trigger boomerang effects. Figure 4 is offered as an example of a student-produced ad, part of a universitywide smoking cessation campaign designed to trigger contemplation by offering actual reasons why students say they smoke. It calls these reasons into question by asking "why" and "why not," but without judgment. 
NOT THE PUBLISHED VERSION; this is the author's final, peer-reviewed manuscript. The published version may be accessed by following the link in the citation at the bottom of the page.

\section{Figure 4.}

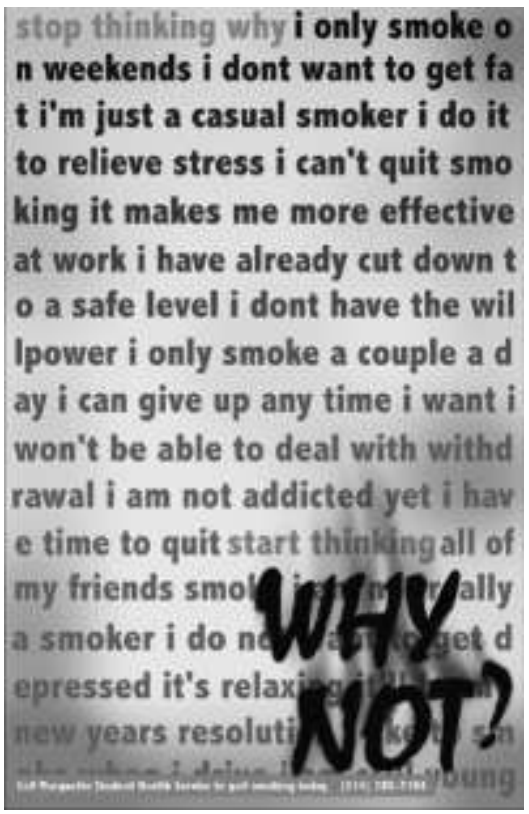

Message from Marquette University's Smoking Cessation Campaign

Some smokers have already contemplated quitting but lack a plan of action. Some ads could address this stage by explicitly providing a reasonable plan of action, which should be developed in consultation with smokers who have successfully quit. Other messages could further build efficacy, which would help maintain their nonsmoking behavior. Such messages might address help lines, Web sites, availability of patches, and other quit smoking aids as well as acknowledging the effort involved and providing emotional support. Because smokers are often unsuccessful in their early attempts and must repeat the cycle, they must not perceive that relapse is a sign of failure. Instead, they need frequent support and encouragement. These strategies are underscored by the comments of student smokers.

\section{Combining Vulnerability with Self-Efficacy and the Desire to Change}

Messages that merely arouse fear should be avoided; however, fear appeals can be used effectively if they are accompanied by selfefficacy messages, which can increase the belief that quitting is both desirable and possible. Such messages may include success stories 
about quitting or information about resources for help. Convincing college student smokers that they are vulnerable is challenging because very few have smoked long enough to develop lifethreatening illnesses. Yet, they fail to recognize that addiction to nicotine can occur very quickly and can be extremely difficult to overcome. Nonjudgmental supportive messages can present factual information intended to heighten awareness of their vulnerability as long as they also increase their feelings of self-efficacy. Thus, a single ad with a dual message of vulnerability and self-efficacy is recommended. Without the efficacy component, risk models predict that heightened awareness of vulnerability alone will lead to fear control behavior (Witte 1994; Wolburg 2001). Presenting the benefits of quitting can also reinforce the message as long as they accurately reflect the reality of smokers instead of nonsmokers.

\section{Avoiding Reactance}

According to reactance theory, smokers will respond negatively to messages that generate a perceived loss of freedom and will dig deeper to hold onto their vice. They will defend their right to smoke and justify their entitlement to small vices. Messages that are likely to generate reactance use authoritarian, judgmental tones that talk down to smokers in a condescending manner using faulty logic or strategies designed to "guilt" them into quitting. Heavy-handedness, insincerity, denying the coolness of smoking, and telling smokers what they already know are formulas for failure. When asked to respond to PSAs, young people often ask for the facts so they are free to draw their own conclusions (Pechmann and Slater 2005). This approach could be combined with the use of spokespersons who are popular among college students.

These findings show that greater targeting of antismoking messages is needed to better serve consumers. What works to prevent young teens from smoking does not necessarily work for college student smokers. Furthermore, what reinforces nonsmokers' decision not to smoke among college students does little to change smokers' behavior. Current messages appear to bolster nonsmokers' commitment; however, some of these messages are not only ineffective among smokers, but they are counterproductive by triggering boomerang responses. Additional research can establish the 
prevalence of these effects, under what conditions they are most likely to emerge, and whether the effects are more strongly linked to fear or to threats to personal freedom. Because students typically feel invincible, the effects are more likely related to threats to personal freedom than fear. However, fear may prove to be the stronger driving force among older people. These relationships bear further investigation so that message strategy can be developed and evaluated for specific audiences. Without continuing to fine-tune the persuasive strategies used in antismoking campaigns, resources are misused and consumers are poorly served.

\section{References}

Agostinelli, Gina, Janice M. Brown, and William R. Miller. 1995. Effects of Normative Feedback on Consumption among Heavy Drinking College Students. Journal of Drug Education, 25 (1): 31-40.

Agostinelli, Gina and Joel W. Grube. 2003. Tobacco Counter-

Advertising: A Review of the Literature and a Conceptual Model for Understanding Effects. Journal of Health Communication, 8 (2): 107-127.

Andreasen, Alan. 1994. Social Marketing: Definition and Domain. Journal of Public Policy \& Marketing, 13 (1): 109-114.

Andrews, Richard L. and George R. Franke. 1991. The Determinants of Cigarette Consumption: A Meta-Analysis. Journal of Public Policy \& Marketing, 10 (1): 81-100.

Bhatti, Jabeen. 2004. European Smokers Snuff Out Cigarette-Package Warnings. Wall Street Journal (February): D4.

Brehm, Jack Williams. 1966. A Theory of Psychological Reactance. New York: Academic Press.

Brehm, Sharon S. and Jack W. Brehm. 1981. Psychological Reactance: A Theory of Freedom and Control. New York: Academic Press.

Bushman, Brad J. and Angela D. Stack. 1996. Forbidden Fruit versus Tainted Fruit: Effects of Warning Labels on Attraction to Television Violence. Journal of Experimental Psychology: Applied, 2 (3): 207-226.

Calkins, Lindsay Noble and Thomas J. Zlatoper. 2001. The Effects of Mandatory Seat Best Laws on Motor Vehicle Fatalities in the United States. Social Science Quarterly, 82 (4): 716-732.

Journal of Consumer Affairs, Vol 40, No. 2 (Winter 2006): pg. 294-323. DOI. This article is (C) Wiley and permission has been granted for this version to appear in e-Publications@Marquette. Wiley does not grant permission for this article to be further copied/distributed or hosted elsewhere without the express permission from Wiley. 
Chassin, Laurie, Clarke C. Presson, and Steven J. Sherman. 1984. Cognitive and Social Influence Factors in Adolescent Smoking Cessation. Addictive Behaviors, 9 (4): 383-390.

Christie-Smith, D. 1999. Smoking-Cessation Programs Need to Target College Students. American Journal of Health-System Pharmacy, 56 (5): 416.

DeLorme, Denise E., Peggy J. Kreshel, and Leonard N. Reid. 2003. Lighting Up: Young Adults' Autobiographical Accounts of Their First Smoking Experiences. Youth \& Society, 34 (4): 468-496. DiFranza, Joseph R., John W. Richards, Jr., Paul M. Paulman, Nancy Wolf-Gillespie, Christopher Fletcher, Richard D. Jaffe, and David Murray. 1991. RJR Nabisco's Cartoon Camel Promotes Camel Cigarettes to Children. Journal of the American Medical Association, 226 (22): 3149-3153.

Duffy, Martyn. 1996. Econometric Studies of Advertising, Advertising Restrictions, and Cigarette Demand: A Survey. International Journal of Advertising, 15 (2): 1-23.

Emmons, Karen M., Henry Wechsler, George Dowdall, and Melissa Abraham. 1998. Predictors of Smoking among US College Students. American Journal of Public Health, 88 (1): 104-107.

Engs, Ruth C. and David J. Hanson. 1989. Reactance Theory: A Test with Collegiate Drinking. Psychological Reports, 64 (3, Pt. 2): 1083-1086.

Farrelly, Matthew, Cheryl G. Healton, Kevin C. Davis, Peter Messeri, James C. Hersey, and M. Lyndon Haviland. 2002. Getting to the "truth": Evaluating National Tobacco Countermarketing Campaigns. American Journal of Public Health, 92 (6): 901-907. Feingold, Paul C. and Mark L. Knapp. 1977. Antidrug Abuse Commercials. Journal of Communication, 27 (1): 20-28.

Fontana, Andrea and James H. Frey. 1994. Interviewing: The Art of Science. In Handbook of Qualitative Research, edited by Norman K.Denzin and Yvonna S.Lincoln (361-376). Thousand Oaks, CA: Sage.

Glaser, Barney G. and Anselm L. Strauss. 1967. The Discovery of Grounded Theory: Strategies for Qualitative Research. Chicago: Aldine.

Goldman, Lisa K. and Sharon A. Glantz. 1998. Evaluation of Antismoking Advertising Campaigns. Journal of the American Medical Association, 279 (10): 772-777. 
Grube, Joel W., Pamela A. Madden, and B. Friese. 1996. The Effects of Television Alcohol Advertising on Adolescent Drinking. Poster session presented at the annual meeting of the Research Society on Alcoholism, Washington, DC.

Healton, Cheryl. 2001. Who's Afraid of the 'truth'? American Journal of Public Health, 91 (4): 554-558.

Huncharek, Michael and Bruce Kupelnick. 2002. Use of Topical Sunscreens and the Risk of Malignant Melanoma: A Metaanalysis of 9067 Patients from 11 Case-Control Studies. American Journal of Public Health, 92 (7): 1173-1177.

Hyland, Michael and James Birrell. 1979. Government Health Warnings and the Boomerang Effect. Psychological Reports, 44 (2): 643647.

Kelder, Steven H., Edward Maibach, John K. Worden, Anthony Biglan, and Alan Levitt. 2000. Planning and Initiation of the ONDCP National Youth Anti-Drug Media Campaign. Journal of Public Health Management Practice, 6 (3): 14-26.

Keller, Punam Anand, Isaac M. Lipkus, and Barbara K. Rimer. 2002. Depressive Realism and Health Risk Accuracy: The Negative Consequences of Positive Mood. Journal of Consumer Research, 29 (1): 57-69.

King, Anthony. 2003. Smokers Support Cigarette-Free Zones. The London Telegraph.

http://www.news.telegraph.co.uk/news/main.jhtml?xml=news/ 2003/12/01/nsmok01.xml.

Lindloff, Thomas R 1995. Qualitative Communication Research Methods. Newbury Park, CA: Sage.

Lorillard Tobacco Company. 2005. Youth Smoking Prevention Program. http://www.lorillard.com/index.php?id=5.

MacKinnon, David P. and Angela Lapin. 1998. Effects of Alcohol Warnings and Advertisements: A Test of the Boomerang Hypothesis. Psychology \& Marketing, 15 (7): 707-726.

McCracken, Grant. 1988. The Long Interview. Newbury Park, CA: Sage.

McKenna, Jeffrey W. and Kymber N. Williams. 1993. Crafting Effective Tobacco Counter-Advertisements: Lessons from a Failed Campaign Directed at Teenagers. Public Health Reports, 108 (1): 85-89.

Journal of Consumer Affairs, Vol 40, No. 2 (Winter 2006): pg. 294-323. DOI. This article is (c) Wiley and permission has been granted for this version to appear in e-Publications@Marquette. Wiley does not grant permission for this article to be further copied/distributed or hosted elsewhere without the express permission from Wiley. 
Miller, William R. and Stephen Rollnick. 1991. Motivational Interviewing: Preparing People to Change Addictive Behavior. New York: Guilford.

Moon-Howard, Joyce. 2003. African American Women and Smoking: Starting Later. American Journal of Public Health, 93 (3): 418420.

Morgan, Mark and Joel W. Grube. 1994. Lifestyle Changes: A Social Psychological Perspective with Reference with Cigarette Smoking among Adolescents. The Irish Journal of Psychology, 15 (1): 179-190.

Neuwirth, Kurt, Edward Frederick, and Charles Mayo. 2002. Person Effects and Heuristic-Systematic Processing. Communication Research, 29 (3): 320-361.

Patterson, Freda, Caryn Lerman, Vyga G. Kaufmann, Geoffrey A.

Neuner, and Janet Audrian-McGovern. 2004. Cigarette Smoking Practices among American College Students: Review and Future Directions. Journal of American College Health, 52 (March/April): 203-211.

Pechmann, Cornelia and Marvin E. Goldberg. 1998. Evaluation of Ad Strategies for Preventing Youth Tobacco Use. In report submitted to the California Tobacco Related Disease Research Program.

Pechmann, Cornelia and Michael D. Slater. 2005. Social Marketing Message That May Motivate Irresponsible Behavior. In Inside Consumption: Perspectives on Consumer Motives, Goals, and Desires, edited by S.Ratneshwar and DavidGlen Mick, pp. 185207. New York: Routledge.

Pechmann, Cornelia, Guangzhi Zhao, Marvin E. Goldberg, and Ellen Thomas Reibling. 2003. What to Convey in Antismoking Advertisements for Adolescents: The Use of Protection Motivation Theory to Identify Effective Message Themes. Journal of Marketing, 67 (2): 1-20.

Prochaska, James O. and Carlo C. DiClememte. 1982. Transtheoretical Therapy: Toward a More Integrative Model of Change. Psychotherapy: Theory Research, and Practice, 19 (3): 276288.

Reppucci, J. D., Tracey A. Revenson, M. Abler, and N. Dickson Reppucci. 1991. Unrealistic Optimism among Adolescent 
Smokers and Nonsmokers. Journal of Primary Prevention, 11 (3): 227-236.

Rigotti, Nancy, Jae Eun Lee, and Henry Wechsler. 2000. U.S. College Students' Use of Tobacco Products: Results of a National Survey. Journal of the American Medical Association, 284 (August): 699-706.

Ringold, Debra Jones. 2002. Boomerang Effect: In Response to Public Health Interventions: Some Unintended Consequences in the Alcoholic Beverage Market. Journal of Consumer Policy, 25 (1): 27-63.

Rotfeld, Herbert J.. 2001. Adventures in Misplaced Marketing. Westport, CT: Quorum Books.

Schorling, John B., Margaret Gutgesell, Paul T. Klas, D. Smith, and A. Keller. 1994. Tobacco, Alcohol, and Other Drug Use Among College Students. Journal of Substance Abuse, 6 (1): 105-115.

Smith, Karen H. and Mary Ann Stutts. 1999. Factors That Influence Adolescents to Smoke. Journal of Consumer Affairs, 33 (2): 321-357.

Smith, Karen H. and Mary Ann Stutts. 2003. Effects of Short-Term Cosmetic versus Long-Term Health Fear Appeals in AntiSmoking Advertisements on the Smoking Behaviour of Adolescents. Journal of Consumer Behaviour, 3 (2): 157-170.

Snyder, Leslie B. and Deborah J. Blood. 1992. Caution: Alcohol Advertising and the Surgeon General's Warning May Have Adverse Effects on Young Adults. Journal of Applied Communication Research, 20 (1): 37-53.

Stutts, Mary Ann, Karen H. Smith, and Gail Zank. 2003. Content Analysis of Select State and Industry Anti-Smoking Advertisements. In Proceedings of the 2003 Conference of the American Academy of Advertising, edited by LesCarlson (248253). Clemson, SC: Clemson University Press.

Taylor, Ronald E. 1994. Qualitative Research. In Mass Communication Research, edited by Michael W.Singletary (265-279). New York: Longman.

U.S. Department of Health and Human Services (USDHHS). 1993. Centers for Disease Control and Prevention, National Center for Health Statistics, NCHS Definitions: Cigarette Smoking. http://www.cdc.gov/nchs/datash/nchsdefs/cigarettesmoking.ht $\underline{\mathrm{m}}$.

Journal of Consumer Affairs, Vol 40, No. 2 (Winter 2006): pg. 294-323. DOI. This article is (c) Wiley and permission has been granted for this version to appear in e-Publications@Marquette. Wiley does not grant permission for this article to be further copied/distributed or hosted elsewhere without the express permission from Wiley. 
U.S. Department of Health and Human Services (USDHHS). 1997. Centers for Disease Control and Prevention. Youth Risk Behavior Surveillance. National College Health Risk Behavior SurveyUnited States. Morbidity and Mortality Weekly Report, 46 (SS6): $1-54$. http://www.cdc.gov/mmwr/preview/mmwrhtml/00049859.htm. U.S. Department of Health and Human Services (USDHHS). 2001. Office of Applied Studies, National Household Survey on Drug Abuse. http://www.oas.samhsa.gov/NHSDA/2k1NHSDA/vo11/Chapter4 htm.

U.S. Department of Health and Human Services (USDHHS). 2004. Centers for Disease Control and Prevention, Tobacco Use at a Glance, Targeting Tobacco Use: The Nation's Leading Cause of Death. http://www.cdc.gov/tobacco/issue.htm.

Vranica, Suzanne. 2003. Critics Fault Antiobesity Ads as Not Reaching Far Enough. Wall Street Journal, Eastern Edition (April): B6.

Wakefield, Melanie, Brian Flay, Mark Nichter, and Gary Giovino. 2003. Effects of Anti-Smoking Advertising on Youth Smoking: A Review. Journal of Health Communication, 8 (3): 229-247. Wechsler, Henry, Toben E. Nelson, Jae Eun Lee, Mark Seibring, Catherine Lewis, and Richard P. Keeling. 2003. Perception and Reality: A National Evaluation of Social Norms Marketing Interventions to Reduce College Students' Heavy Alcohol Use. Quarter Journal of Studies on Alcohol, 64 (4): 484-494.

Weinstein, Neil D. 1998. Accuracy of Smokers' Risk Perceptions. Annals of Behavioral Medicine, 20 (2): 135-140.

Wetter, David W., Susan L. Kenford, Samuel K. Welsch, Stevens S. Smith, Rachel T. Fouladi, Michael C. Fiore, and Timothy B. Baker. 2004. Prevalence and Predictors of Transitions in Smoking Behavior among College Students. Health Psychology, 23 (2): 168-177.

- Witte, Kim. 1991. The Role of Threat and Efficacy in AIDS Prevention. International Quarterly of Community Health Education, 12 (3): 225-249.

- Witte, Kim. 1994. Fear Control and Danger Control: A Test of the Extended Parallel Process Model (EPPM). Communication Monographs, 61 (2): 113-134.

Journal of Consumer Affairs, Vol 40, No. 2 (Winter 2006): pg. 294-323. DOI. This article is @ Wiley and permission has been granted for this version to appear in e-Publications@Marquette. Wiley does not grant permission for this article to be further copied/distributed or hosted elsewhere without the express permission from Wiley. 
NOT THE PUBLISHED VERSION; this is the author's final, peer-reviewed manuscript. The published version may be accessed by following the link in the citation at the bottom of the page.

- Wolburg, Joyce. 2001. The 'Risky Business' of Binge Drinking among College Students: Using Risk Models for PSAs and AntiDrinking Campaigns. Journal of Advertising, 30 (4): 23-40. 